\title{
The Realization of Maqoshid Shari'ah as Local Values in Industrial Relations Disputes Resolution Efforts
}

\author{
Asri Wijayanti ${ }^{1 *}$ Slamet Suhartono ${ }^{2}$ Mahsun $^{3}$ Muridah Isnawati $^{1}$
}

\author{
${ }^{1}$ Faculty of Law, University of Muhammadiyah Surabaya, Surabaya, Indonesia \\ ${ }^{2}$ Faculty of Law, University of 17 Agustus 1945 (UNTAG), Surabaya, Indonesia \\ ${ }^{3}$ Faculty of Teacher Training and Education, University of Muhammadiyah Surabaya, Surabaya, Indonesia \\ ${ }^{*}$ Corresponding author. Email: asri.wijayanti@fh.umsurabaya.ac.id
}

\begin{abstract}
In the era of globalization, the role of Trade Unions is very important. Trade Unions can represent workers in industrial relations dispute resolution and carry out activities to improve workers' welfare. Trade Unions can sometimes take unwise actions that cause suspicion to others. The problem in this research can be solved by planting Maqoshid Sharia in the value of local wisdom as a model in the efforts to resolve the industrial relations disputes among union administrators. The purpose of this study is to provide an overview of the implementation of the value of maqoshid sharia as an alternative solution in the efforts to resolve industrial relations disputes. This research is juridically normative with conceptual and statutory approaches. The results of this study are Maqoshid Sharia which is the goal of Islamic law has two dimensions, namely al wujud and al adam. Consisting of five things, namely laying the foundation of goodness to maintain religion, self, nasab, wealth and reason. Everything has three levels, namely dhoruriyat, hajjiyat and tahsiniyat. These three levels must be implemented by the management of trade unions when facing a conflict of problems based on their priority level as the efforts to resolve industrial relations disputes through litigation or non-litigation. The conclusion was that the trade unions must understand the roots of the disputes object of the industrial relations that occur. Furthermore, it would try to achieve the goodness by conducting a problem analysis based on Maqoshid Sharia to determine the strategical implementation of the three levels of Maqoshid Sharia, namely dhoruriyat, hajjiyat and tahsiniyat)
\end{abstract}

Keywords: maqoshid sharia, local values, industrial relations disputes, trade unions, workers

\section{INTRODUCTION}

The community continues to grow from time to time. Starting from primitive society to the revolutionary period [1]. The revolution continues to roll from 1.0, 2.0, 3.0, to 4.0 revolutions [2] towards 5.0 society. There are no more state boundaries in conducting communication and legal relations. The era where everyone is able to connect with each other via the internet which is often called globalization era.

Globalization is the process of interaction and integration among people, institutions / legal entities and governments from country to country; a process that is driven by international trade and investment and assisted by information technology [3]. In the globalization era, everyone can take a role based on their competencies. It can cause the positive and negative impacts, [4] as well as inequality in society. [5] and also in the industrial community.

One of inequality forms in society is the occurrence of industrial relations disputes. Industrial relations disputes can be avoided by the positive role of the parties to take a preventative action. Every actor in industrial relations can take an active role. All actors have a very important roles for business continuity and improving the prosperity of employees. Both employers, employees and the government must have active roles to maintain conducive industrial relations. All parties must try together to create a balance for two different interests. The government can be a supervisor or facilitator in the implementation of industrial relations. Trade unions have a very important role, [6] sometimes the government has not facilitated trade unions to have a strong bargaining position. [6] The employers represented by their management should also have an important role in determining the state policy. [7] There are challenges that must be overcome.

All countries are currently trying to make a concept to overcome the challenges of the effects of globalization. [6] The challenge is to balance the interests of productivity (market continuity) and of improving workers' welfare. In the era of globalization, the role of trade unions is very important. [8] Trade Unions can act as workers 'representatives in resolving industrial relations disputes and conducting activities to improve workers' welfare. Trade union officials can sometimes take unwise actions that can cause suspicion in others. An effort is needed to improve the quality of trade unions in the role of sustaining industrial relations. 
The problem of this research is whether the maqoshid shari'ah can be used by trade unions as one of the basic alternatives for resolving industrial relations disputes. The purpose of this study is to provide an overview of the implementation of maqoshid sharia values as an alternative solution as the effort of resolving industrial relations disputes.

\section{METHOD}

This research is normative legal research using statute and conceptual approach. Normative legal research is a legal research that places law as the norm system. The norm system consists of principles, norms, laws, court judgments, agreements and doctrines or teachings. The method used in legal research conducted by examining the legal materials as existing library. The main legal research material is the rule of law and court judgement. Analysis of legal materials on the issues under the study is using interpretation or legal construction.

\section{RESULTS AND DISCUSSIONS}

\section{A. The Function of Trade Unions in Industrial Relations Disputes}

Industrial relations disputes are defined as disputes between employers or joint employers and workers or trade unions due to the disputes of rights, interests, layoffs and the disputes among trade unions within a company (Article 1 number 1-4 Law 2/2004).

Industrial relations disputes are labor disputes. [9] Labor disputes in general can be divided into disputes of rights and interests. The difference is whether there is a rule underlying the dispute itself. The dispute of rights is caused by not implementing rules made by the parties (work agreements, collective labor agreements, company regulations) and or statutory regulations. A dispute of interests is caused by something that are not yet regulated by internal rules or regulations.

The actors in industrial relations must play an active role in preventing the occurrence of labor disputes, through the exercise of their respective functions. The function of the government is to establish policies, provide services, conduct supervision, and take action against violations of labor laws and regulations. The function of workers or laborers and their trade unions is to carry out work in accordance with their obligations, maintain an order for the continuation of production, express the aspirations democratically, develop the skills, and expertise and participate in promoting companies and struggling for the welfare of members and their families. The function of employers and their employers' organizations is to create partnerships, develop businesses, expand employment opportunities, and provide welfare for workers or laborers openly, democratically and equally.
The function of trade union has been stipulated in the previous law, namely as a party in making collective labor agreements and industrial dispute settlement; as worker or labor representative in company in labor relations based on the level; as a means of creating harmonious, dynamic and fair industrial relations in accordance with applicable laws and regulations; as a means of expressing aspirations in struggling with the rights and interests of its members; as the planner, executor, and person in charge of the workers' strike in accordance with the applicable laws and regulations; as a worker or labor representative in the struggling with share ownership in the company.

For this function, trade unions have the right to make collective work agreements with employers; represent workers or laborers in resolving industrial disputes; represent workers or laborers in labor institutions; forming institutions or carrying out activities related to efforts to improve the welfare of workers or laborers; carry out other activities in the field of employment that are not in conflict with applicable laws and regulations.

In order to carry out its functions and rights, trade unions need a well preparation to improve the quality of their role in creating conducive industrial relations.

\section{B. Maqoshid Sharia as Local Values}

Maqoshid sharia is the goal or lesson for the enactment of law. That is aimed at realizing human benefit in the world and the hereafter (Syatibi). Maqoshid sharia includes: Hifzhu al-Din (guarding and protecting the existence of religion); Hifzhu al-nafs (guarding and protecting lives); Hifzhu al-Aql (guarding and protecting the mind); Hifzhu al-Maal (guarding and protecting property) and Hifzhu alNasab (guarding and protecting offspring). [10]

Maqoshid Sharia is essentially manifesting benefit through providing benefits (jalb al-manafi) and avoiding damage (dar'u al ma-mafasid). Benefits can be realized if the implementation of five main elements (usul al-khamsah) namely religion (al-din), soul (al-nafs), descent (nasab or alnasl), treasure (al-mal) and reason (al-'aql).

Maqoshid sharia can be found in the teachings of Islam. The teachings of Islam became the basis for the formation of the Islamic legal system. Islamic law can be easily applied or implemented in society. This is because Islam revealed by Allah to give mercy to all humans in the world. Islam has the function of rahmatin lil alamin. [11]

On the basis of rahmatin lil alamin, Islam can become a living value in society which then becomes local values or local wisdom. Local Wisdom becomes a matter of great concern and respect in Islam for its people as social beings, as long as it is appropriate and not violating the Sharia according to the provisions of the Al Quran and Hadits which must be respected. Local values are full of religious values accepted by the community.

Local values are carried out through the process of adoption, adaptation and assimilation. [12] Islamic values can easily get in the lives of Indonesian people. For example, Ki Hajar Dewantara (real name: Suwardi Suryaningrat) who is able to formulate Islamic values into the principle of leadership 
in a local value, that is "in ngarsa sung tulada, ing madya mangun karsa, tut wuri handayani". This principle consists of three elements. The first element is "ing ngarsa sung tulada" which means when the leaders stand in the front they must be able to set an example to those who are led. they must be really prepared and know that what they are doing are good and right. The second principle is "ing madya marsa karsa" means that when a leader is in the middle, he must be able to inspire enthusiasm, be committed and creative to those who are led. Can provide positive input and direction. The third principle is "tut wuri handayani" which means when the leader is behind, he has to follow and direct the people behind to be brave to walk ahead and be able to take responsibility.

The principles of law taught by Ki Hajar Dewantara in "ing ngarsa sung tulada, ing madya mangun karsa, tut wuri handayani"are the embodiments of self-realization in the purpose of Islamic teaching. [13] Unity can be achieved by implementing the five basic elements (al-khamsah), namely religion (al-din), soul (al-nafs), descent (nasab or al-nasl), treasure (al-mal) and mind (al-'aql). Of course anyone who practices the five Islamic goals must have been able to reflect the Prophet's characters of shiddiq (truthfulness), amanah (trustworthiness), tabligh (commandable), and fathanah (intelligent).

\section{Maqoshid Syaria as the Basis for Settlement of Industrial Relations Disputes}

Industrial relations disputes in Indonesia can be divided into four types, namely disputes of rights, interests, layoff and disputes between trade unions in a company.

Trade union has the function and the right to prevent and resolve industrial relations disputes. Actions need to be taken by trade union officials to improve their quality. One of the efforts is by increasing knowledge, understanding and skills to be realized in all its actions to achieve a conducive and harmonious condition of industrial relations.

Efforts to increase the knowledge, understanding and skills of trade unions can be obtained from implementing local values outside of the country. Local values are very important for people's lives, especially in the era of globalization. We can incorporate foreign values into local life by fulfilling the conditions, which can increase the level of our lives by developing our belongings and enriching the missings things from us. One of the foreign values which has become A local value is maqoshid sharia.

Maqoshid Sharia is essentially manifesting benefit through providing benefits (jalb al-manafi) and avoiding damage (dar'u al ma-mafasid). The implementation of the Maqoshid Sharia in the effort to prevent and resolve industrial relations disputes by the Trade Unions is based on the implementation of the law for the benefit of the world and the hereafter. Maqoshid Sharia consists of Hifzhu al-Din (guarding and protecting the existence of religion); Hifzhu al-nafs (guarding and protecting lives); Hifzhu al-Aql (guarding and protecting the mind); Hifzhu al-Maal (guarding and protecting property) and Hifzhu al-Nasab (guarding and protecting offspring).
The first implementation of the Maqoshid Sharia, namely hifzhu al-Din which means guarding and protecting the existence of religion can be seen from the legal protection of workers to carry out worship. There is really a principle of no work no pay. [14] This principle cannot be applied to workers when workers carry out worship which is ordered by their religion 5 This provision is a manifestation of the protection of the right to worship in the constitution. 6 Its implementation in the company must be wise. This is because the worship is very broad. Can be distinguished in two ways, namely worship of Allah SWT and worship in connection with other fellow creatures of God. An understanding of the types of worship that can be excluded from the principle of no work no pay is needed. The distinction must be divided into three levels of needs, namely as dhoruriyat (primary), hajjiyat (secondary) or tahsiniyat (tertiary).

Performing the five daily prayers is the primary need of every Muslim which is primary. There is no reason for employers to forfeit the right to pray, such as the prohibition of Friday prayers for male Muslim workers. The order to perform the five daily prayers is only during the day or night by combining the Duhur and Ashr and Maghrib and Isha prayers'. If industrial relations disputes are the root of the problem here, then, Trade Unions must absolutely fight for it. The completion target is $100 \%$ and there is no win-win solution.

It would be different if performing the pilgrimage, a winwin solution could be applied in a mutual agreement. It can be determined jointly between the employer and the trade union about the amount and time of pilgrimage which can be carried out with the principle of no work no pay.

The second implementation of the Maqoshid Sharia, namely hifzhu al-nafs (guarding and protecting souls and lives) can be seen from the protection of the right to life and defends the life. 7 The explanation is the protection of social security for workers. 8 The right to life is the highest basic right. The UN has set rights to life as the highest basic rights before the freedom. The third basic right is security of person.9 Related to the protection of hifzhu al-nafs (soul), it is the protection of reproductive rights for women workers. Protection during pregnancy, childbirth, breastfeeding a child, uterine pregnancy and illness during menstruation must be enforced absolutely. Trade unions must be able to fight for the implementation of reproductive rights.

The third implementation of the Maqoshid Sharia, hifzhu al-Aql (guarding and protecting the mind) can be seen from the protection of working hours. The time of day given by God is 24 hours. It can be divided into three in every 8 hours. 8 hours for worship, work and rest. For this reason, the set working hours is 108 hours or 40 hours per week. Islam regulates the use of day time to seek the gift of Allah (work) and the night to rest. One of the propositions is

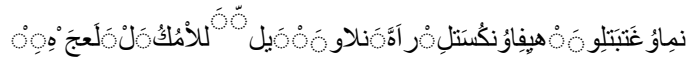

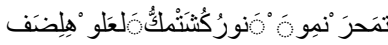


It is out of His Mercy that He has made for you night and day that you may repose (during the night) and seek His Bounty (during the day) that you might be grateful." (https://www.islamicstudies.info/tafheem.php?sura=28\&ve rse $=68 \&$ to $=75$ )

There is a natural biological clock actually. It can not be denied when someone uses the night time to work will affect the health of the body and soul. A good understanding of the employer is needed to manage work time as efficiently as possible without overtime. Japan has already implemented this. For alternative solutions, it should be possible to arrange wages per hour.

The forth implementation of the Maqoshid Sharia, hifzhu al-Maal (guarding and protecting property) can be seen in protecting property rights that cannot be taken arbitrarily by anyone.11 Not only workers are protected by Law 13/2003. The employers or businessmen also receive the same protection. This is based on the philosophy of labor law which places a balance between productivity and welfare. When strikes occur and affraid of damage on the property of company, then the activities on the workplace could be stopped. The protection against the company's property is a secondary or tertiary need. Universally, property right is on the third basic right, namely security of person. 12

The fifth implementation of the Maqoshid Sharia, namely hifzhu al-Nasab (guarding and protecting descendants), can be seen in marital protection. Every person has the right to establish a family and continue descendants through a legal marriage. Every child has the right to survival, growth and development and is entitled to protection from violence and discrimination.13 There must not be any reason for LGBT justification (lesbian, gay, bisexual and transgender / transsexual)

If the trade union is able to fight for the five goals above, then it has tried to realize the character of Rasulullah SAW, namely shiddiq (true in his words and actions), amanah (trustworthy to carry out responsibilities), tabligh (convey information correctly) and fathonah (intelligent). Trade union officials are required to have 4 Rasullallah characters in order to be able to carry out efforts to resolve industrial relations disputes based on maqoshid sharia.

To implement maqoshid sharia in the implementation of efforts to prevent and resolve industrial relations disputes or conflicts, it can be done by applying the Javanese traditional philosophy that has been formulated by Kihajar Dewantoro, namely ing ngarso sung tulodho, ing madya mangun karso, tutwuri handayani. The realization of the implementation of this principle is to first do a case analysis by finding the root cause of each case to be handled.

Ki Hadjar Dewantara provides directives namely "tetepmantep-antep", "ngandel-kendel-stubborn-candel" and "Neng-ning-nung-nang". [13] Anyone who is calm will clear his mind, can easily distinguish between goods that are rights and which are not, right and wrong, so that he will be strong, firm in his will, solidly born physically and mentally, to achieve what he wants, eventually he will win, and finally entitled to the results of his efforts.

"Tetep" or commit for yourself is the essence to achieve what we want, focus on our work, do not always look right and left. In accordance with the stages of our plans. "Mantep" or heartened, so that there will be no strength that will hold our steps or deflect our steps. So that our actions will be automatically strong or heavy (weighted ) and we are not easily detained, inhibited or opposed. "Ngandel" or believe means to believe in Allah SWT and self-power. "Kendel" or brave, that is avoiding fear or suspicion. "Bandel" or hold, trust, heart strong suffer. "Kandel" or thick, which despite suffering but strong body and physical. These four traits are interconnected: "whoever can believe will certainly be brave, then he will be easy to trust and naturally he will be thick." c. "Neng", means "calm", that is peace of mind and body. "Ning" from the words "wening" and "bening" means clear mindedness. It is easy to distinguish between valid and invalid things, right and wrong."Nung" from the word "hanung" means strong, peaceful will, firm in all strengths, physically and mentally, to achieve what it wants "Nang" which is "to win" or to be "authorized" or entitled to the efforts. These four traits are interconnected: anyone who can "neng" is certainly easy to think "ning", then be strong or "nung" of the will, and will automatically "win".

One important thing in carrying out procedures for resolving industrial relations disputes is our care to always seek formal evidence. Due to the procedural law used in the proceedings at the Industrial Relations Court is a civil procedural law. The strongest and first proof of evidence in civil procedural law is a deed or written evidence.

Islam teaches us the importance of recording all commercial or legal relations. The proposition for the importance of formal truth is in holy Quran surah Al Baqoroh verse 282 [15], namely:

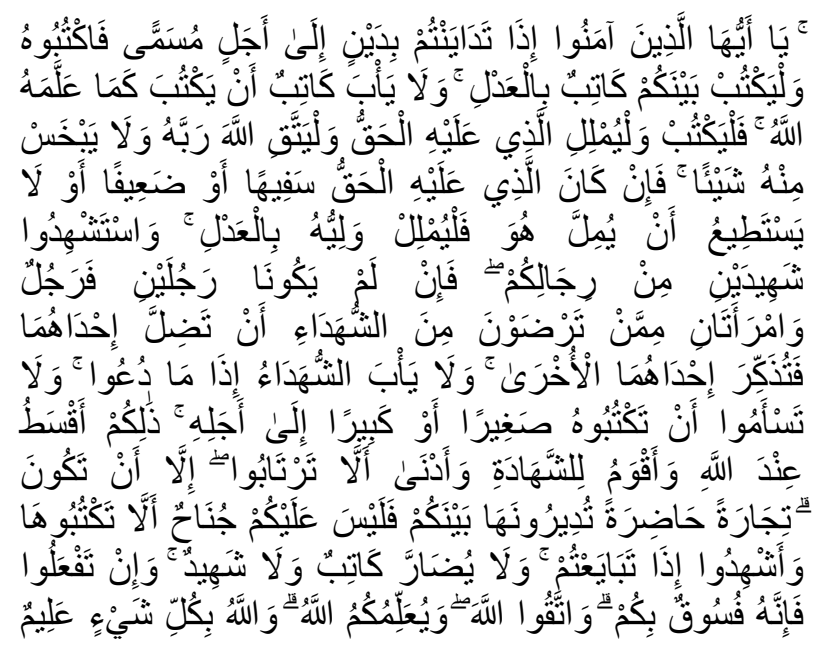

"Believers! Whenever you contract a debt from one another 
for a known term, commit it to writing. Let a scribe write it down between you justly, and the scribe may not refuse to write it down according to what Allah has taught him; so let him write, and let the debtor dictate; and let him fear Allah, his Lord, and curtail no part of it. If the debtor be feebleminded, weak, or incapable of dictating, let his guardian dictate equitably, and call upon two of your men as witnesses; but if two men are not there, then let there be one man and two women as witnesses from among those acceptable to you, so that if one of the two women should fail to remember, the other might remind her. Let not the witnesses refuse when they are summoned (to give evidence). Do not show slackness in writing down the transaction, whether small or large, along with the term of its payment. That is fairest in the sight of Allah; it is best for testimony and is more likely to exclude all doubts. If it be a matter of buying and selling on the spot, it is not blameworthy if you do not write it down; but do take witnesses when you settle commercial transactions with one another. And the scribe or the witness may be done no harm."

It will be sinful if you do so. Beware of the wrath of Allah. He teaches you the Right Way and has full knowledge of everything.

If the maqoshid sharia which has become a local wisdom is carried out by trade union officials, the harmonious and conducive industrial relations will be achieved easily. There is a Javanese proverb that is "rukun agawe santoso, congkrah agawe bubrah". It means that a harmony will form a power. A harmonious life is described by openness to a variety of differences, ranging from race, ethnicity, skin color and religion. So that mutual acceptance will form unity. Just like a physical consisting of a lot of parts of the body.

\section{CONCLUSION}

Trade unions must understand the roots of the object of industrial relations disputes. Furthermore, trying to achieve goodness by analyzing problems based on maqashid sharia to determine the strategy of applying the three levels of maqashid sharia namely dhoruriyat, hajjiyat and tahsiniyat.

\section{ACKNOWLEDGMENT}

Thank you to the Ministry of Research and Technology for funding basic research in the 2019 fiscal year, entitled "Model of Trade Union Advocacy in Formal Truth-Based Industrial Relations Disputes in Indonesia".

\section{REFERENCES}

[1] L. Da Xu, L. Li, and E. L. Xu, "Industry 4.0: State of the art and future trends," Int. J. Prod. Res., vol. 56, no. 8, pp. 1-22, 2018.
[2] V. Roblek, M. Meško, and A. Krapež, “A Complex View of Industry 4.0," J. Sage Open, vol. 6, no. 2, pp. 1-11, 2016.

[3] K. E. I. Smith, Sociology of Globalization Cultures, Economies, and Politics. New York: Routledge, 2018.

[4] H. H. Khondker, "Globalization and inequality," Sage Journals, vol. 32, no. 2, pp. 170-179, 2017.

[5] C. . Ibsen and M. Tapia, "Trade Union Revitalisation: Where are we now? Where to Next?," J. Ind. Relat., vol. 2, no. 1, pp. 170191, 2017.

[6] L. Babcock, W. J. Congdon, L. F. Katz, and S. Mullainathan, "Notes on behavioral economics and labor market policy," IZA J. Labor Policy, vol. 1, no. 2, pp. 1-22, 2012.

[7] EEA, The European environment - state and outlook 2010: synthesis. Copenhagen: European Environment Agency, 2010.

[8] M. Flynn, M. Upchurch, and M. Muller-Camen, "Trade union responses to ageing workforces in the UK and Germany," Journdal Index. Metrics, vol. 66, no. 1, pp. 45-64, 2013.

[9] M. Gallagher, J. Giles, and A. Park, "China's 2008 Labor Contract Law: Implementation and implications for China's workers," Sage Journals, vol. 68, no. 2, pp. 197-235, 2015.

[10] F. K. Rahman, M. A. Tareq, R. A. Yunanda, and A. Mahdzir, "Maqashid Al-Shari'ah-based performance measurement for the halal industry," J. Humanomics, vol. 33, no. 3, pp. 357-370, 2017.

[11] O. Leaman, "Islam in the Routledge Companion to Theism," Taylor Fr., vol. 3, no. 1, pp. 66-76, 2012.

[12] L. Mydland and W. Grahn, "Identifying heritage values in local communities," International Journal of Heritage Studies," Int. J. Herit. Stud., vol. 18, no. 1, pp. 564-587, 2012.

[13] H. M. Zulfiati and Chairiyah, "Implementation of Cultural school as Character Education based on Ki Hadjar Dewantara in Elementary

School," Int. Converence Educ. Sci., vol. 1, no. 1, pp. 46-93, 2017.

[14] O. AH, H. H, F. J, and D. EL, "Show them the money? The role of pay, managerial need support, and justice in a self-determination theory model of intrinsic work motivation," $J$. Psychol., vol. 56, no. 4, pp. 447-457, 2015.

[15] Nurhaila, "Islamic Accounting Concept In AlQuran And Its Implementation In Indonesia," Hum. Falah, vol. 3, no. 2, pp. 1-16, 2016. 